\title{
Outcomes of Take-Back Operations in Breast Reconstruction with Free Lower Abdominal Flaps
}

\author{
Ji Hong Yim ${ }^{1}$, Jiyoung Yun ${ }^{1}$, Taik Jong Lee ${ }^{1}$, Eun Key Kim, Jonghan Cho ${ }^{2}$, Jin Sup Eom ${ }^{1}$ \\ ${ }^{1}$ Department of Plastic Surgery, Asan Medical Center, University of Ulsan College of Medicine, Seoul; ${ }^{2}$ Seoul Plastic Surgery Clinic, \\ Gangneung, Korea
}

Background Microvascular complications after free-flap breast reconstructions are potentially devastating problems that can increase patient morbidity and lead to flap loss. To date, no comprehensive study has examined the rates of salvage and the methods of microvascular revision in breast reconstruction. We reviewed the treatment of microvascular complications of free-flap breast reconstruction procedures over a seven-year period.

Methods A retrospective review of all patients who underwent microvascular breast reconstruction at our institution between April 2006 and December 2013 was conducted. Based on their surgical records, all patients who required emergency re-exploration were identified, the rate of flap salvage was determined, the factors associated with flap salvage were evaluated, and the causes and methods of revision were reviewed.

Results During the review period, 605 breast reconstruction procedures with a free lower abdominal flap were performed. Seventeen of these flaps were compromised by microvascular complications, and three flaps were lost. The overall salvage rate was $82.35 \%$. No significant differences between the salvaged group and the failed group were observed with regard to age, BMI, axillary dissection, number of anastomotic arteries and veins, recipient vessel types, or use of the superficial inferior epigastric vein in the revision operation. Successful salvage of the flap was associated with a shorter time period between recognizing the signs of flap compromise and the take-back operation.

Conclusions The salvage rate of compromised lower abdominal flaps was high enough to warrant attempting re-exploration. Immediate intervention after the onset of flap compromise signs is as important as vigilant postoperative monitoring.

Keywords Perforator flap / Surgical flaps / Free tissue flaps / Salvage therapy / Breast
Correspondence: Jin Sup Eom Department of Plastic Surgery, Asan Medical Center, University of Ulsan College of Medicine, 88 Olympic-ro 43-gil, Songpa-gu, Seoul 05505, Korea

Tel: +82-2-3010-3602

Fax: +82-2-476-7471

E-mail: jinsupp@amc.seoul.kr

The authors thank all the professors and colleagues in the Departments of Plastic Surgery at the Asan Medical Center and the University of Ulsan College of Medicine.

No potential conflict of interest relevant to this article was reported.

Received: 28 May 2015 - Revised: 23 Sep $2015 \bullet$ Accepted: 5 Oct 2015

pISSN: 2234-6163 • elSSN: 2234-6171 • http://dx.doi.org/10.5999/aps.2015.42.6.741 • Arch Plast Surg 2015;42:741-745

\section{INTRODUCTION}

The free flap has undergone important technical improvements and is now a reliable method of reconstructing surgical defects, with a success rate of over $91 \%[1,2]$. Free flaps made of lower abdominal tissue are being increasingly used in breast recon- struction, and have become the most commonly adopted method among the options for breast reconstruction using autologous tissue. However, lower abdominal free flaps may experience microvascular complications that can potentially lead to flap loss. As the purpose of breast reconstruction is not merely to provide coverage of the defect, but also to restore the sym- 
metric shape and volume of the breast, a compromised flap in a breast reconstruction procedure may be more emotionally traumatic to the patient than in other operations.

Many reports have evaluated free-flap salvage in reconstruction of the head and neck region or the lower extremity [1-3]. To date, no comprehensive analysis of the factors associated with flap salvage or loss in free-flap breast reconstruction has been published. We therefore reviewed cases of free lower abdominal flap breast reconstructions and investigated the factors that were associated with success in take-back operations performed to save the flaps with microvascular complications. In our study, the term "take-back operation" is used to refer to a revision operation to salvage a flap that was compromised by a vascular insult.

\section{METHODS}

A retrospective chart review was performed of 605 cases of free lower abdominal flap breast reconstruction carried out between April 2006 and December 2013. Immediate reconstruction was performed in 566 cases and delayed reconstruction was performed in 39 cases. In this cohort, a deep inferior epigastric perforator (DIEP) flap was used in 304 cases, while a muscle-sparing free transverse rectus abdominis musculocutaneous (TRAM) flap was used in 301 cases. Of the 605 cases that we initially screened, 17 required a take-back operation due to circulatory compromise and were subjected to further analysis. We divided the 17 cases of take-back operations into two groups, depending on whether the flap was successfully salvaged or the take-back operation failed. We then considered age, body mass index (BMI), smoking, axillary node dissection, the type of recipient vessels, and use of the superficial inferior epigastric vein (SIEV) as factors that could potentially affect the outcomes of salvage surgery. In order to evaluate the time interval between the initial operation and the take-back operation, we measured and compared the interval from the completion of the primary operation to the first recognition of the signs of microvascular compromise (time A), and the interval from the first recognition of the signs of microvascular compromise to the commencement of the revision operation (time B). For statistical analysis, Fisher's exact test was used for categorical variables, the two-sample $\mathrm{t}$ test was used for continuous variables, and the Wilcoxon ranksum test was used for comparing time A and time B. P-values $<0.05$ were considered to indicate statistical significance.

\section{RESULTS}

Three cases of flap loss occurred in the 17 take-back opera- tions. In the other 14 cases, the flaps were successfully salvaged either by reanastomosis of the main pedicle or establishing an alternative drainage with the SIEV. The success rate of the takeback operations was $82.4 \%$. Detailed information about the flaps and revision operations are presented in Table 1, in which the numbering of the patients reflects the chronological order of operation. The SIEV was used with the supercharging technique in the primary operation in two patients. The initial cause of flap compromise was venous thrombosis in 12 cases, venous insufficiency without thrombosis in four cases, and arterial thrombosis in one case. The procedures that were performed to save the congested flap all attempted to re-establish venous outflow. Thrombectomy and reanastomosis of the deep inferior epigastric vein (DIEV) was performed in 11 cases. SIEV anastomosis was performed in eight cases. In four cases, the SIEV was used as additional venous augmentation, while in the other four cases, the SIEV was used for main venous outflow after abandoning the DIEV. Arterial thrombectomy and reanastomosis were performed in five cases. During a follow-up period of six months or more, fat necrosis with a size of $1 \mathrm{~cm}$ or more was observed in five of the 14 patients in the salvaged group.

No significant differences were found between the salvaged group and the failed group with regard to age, BMI, axillary dissection, the extent of muscle sparing, the number of arteries and veins, and type of recipient vessel. No statistically significant differences were observed between the outcomes of cases in which SIEV was used or not used, but all eight cases in which the SIEV was used in the re-exploration were successfully salvaged (Table 2). All 17 patients were non-smokers, and smoking was therefore not analyzed as a factor.

The average time A was 16.57 hours in the salvaged group and three hours in the failed group, which was a statistically significant difference $(\mathrm{P}=0.023)$. The average time $\mathrm{B}$ was 4.82 hours in the salvaged group and 29 hours in the failed group, which was likewise a statistically significant difference $(\mathrm{P}=0.032)$ (Table 3$)$.

\section{DISCUSSION}

Microsurgical free tissue transfer is currently considered to be a reliable option for breast reconstruction [4-6]. However, even when this procedure is performed by the most experienced surgeons, microvascular compromise of the flap can still occur. Our flap success rate was $99.5 \%$, but it must not be forgotten that experiencing microsurgical complications can be extremely stressful and traumatic for the patients. Hence, every precaution should be taken to avoid vascular compromise and to ensure a maximally high success rate. Information about fat necrosis and partial necrosis in the salvaged flaps is also valuable and worthy 
Table 1. Individual characteristics of the 17 cases who required a revision operation

\begin{tabular}{|c|c|c|c|c|c|c|c|c|c|c|c|}
\hline $\begin{aligned} \text { Case } \\
\text { no. }\end{aligned}$ & $\begin{array}{l}\text { Age } \\
\text { (yr) }\end{array}$ & $\begin{array}{c}\mathrm{BMI} \\
\left(\mathrm{kg} / \mathrm{m}^{2}\right)\end{array}$ & $\begin{array}{l}\text { Type of } \\
\text { mastectomy }\end{array}$ & $\begin{array}{l}\text { Type of } \\
\text { muscle } \\
\text { sparing }\end{array}$ & $\begin{array}{l}\text { Final } \\
\text { flap } \\
\text { weight } \\
\text { (g) }\end{array}$ & $\begin{array}{l}\text { Use of the } \\
\text { SIEV in } \\
\text { primary } \\
\text { operation }\end{array}$ & $\begin{array}{l}\text { Recipient } \\
\text { arteryl } \\
\text { vein } \\
\text { in primary } \\
\text { operation }\end{array}$ & $\begin{array}{l}\text { Cause of } \\
\text { flap } \\
\text { compromise }\end{array}$ & $\begin{array}{l}\text { Use of SIEV } \\
\text { in revision } \\
\text { operation }\end{array}$ & $\begin{array}{l}\text { Revision } \\
\text { procedure }\end{array}$ & $\begin{array}{c}\text { Final } \\
\text { outcome }\end{array}$ \\
\hline 1 & 31 & 22.35 & SSM & I & 446 & No & TDA/TDV & $\begin{array}{l}\text { Venous } \\
\text { thrombosis }\end{array}$ & No & Change of recipient vein to LTV & Salvaged \\
\hline 2 & 37 & 22.68 & SSM & III (DIEP) & 458 & No & TDA/TDV & $\begin{array}{l}\text { Venous } \\
\text { thrombosis }\end{array}$ & No & Vein reanastomosis & Salvaged \\
\hline 3 & 38 & 20.12 & SSM & III (DIEP) & 339 & No & TDA/TDV & $\begin{array}{l}\text { Venous } \\
\text { insufficiency }\end{array}$ & Yes (to LTV) & Supercharge with SIEV & Salvaged \\
\hline 4 & 35 & 23.15 & NSM & III (DIEP) & 445 & No & LTA/TDV & $\begin{array}{l}\text { Arterial } \\
\text { thrombosis }\end{array}$ & No & Artery reanastomosis & Failed \\
\hline 5 & 51 & 23.45 & NSM & III (DIEP) & 460 & Yes (to LTV) & TDA/TDV & $\begin{array}{l}\text { Venous } \\
\text { thrombosis }\end{array}$ & Reanastomosis & $\begin{array}{l}\text { SIEV reanastomosis with vessel } \\
\text { graft }\end{array}$ & Salvaged \\
\hline 6 & 44 & 21.91 & NSM & III (DIEP) & 225 & No & IMA/IMV & $\begin{array}{l}\text { Venous } \\
\text { thrombosis }\end{array}$ & Yes (to TDV) & $\begin{array}{l}\text { Arterial and vein reanastomosis } \\
\text { Supercharge with SIEV }\end{array}$ & Salvaged \\
\hline 7 & 34 & 21.22 & SSM & $\|$ & 222 & No & IMA/IMV & $\begin{array}{l}\text { Venous } \\
\text { thrombosis }\end{array}$ & Yes (to TDV) & $\begin{array}{l}\text { Vein reanastomosis } \\
\text { Supercharge with SIEV }\end{array}$ & Salvaged \\
\hline 8 & 41 & 22.10 & SSM & III (DIEP) & 197 & No & IMA/IMV & $\begin{array}{l}\text { Venous } \\
\text { insufficiency }\end{array}$ & $\begin{array}{l}\text { Yes (to IMV } \\
\text { perforator) }\end{array}$ & Supercharge with SIEV & Salvaged \\
\hline 9 & 40 & 18.96 & NSM & III (DIEP) & 417 & No & IMA/IMV & $\begin{array}{l}\text { Venous } \\
\text { insufficiency }\end{array}$ & No (unavailable) & Vein reanastomosis & Failed \\
\hline 10 & 41 & 26.03 & SSM & III (DIEP) & 588 & No & IMA/IMV & $\begin{array}{l}\text { Venous } \\
\text { thrombosis }\end{array}$ & Yes (to IMV) & $\begin{array}{l}\text { Artery reanastomosis } \\
\text { SIEV anastomosed to IMV }\end{array}$ & Salvaged \\
\hline 11 & 42 & 29.60 & NSM & III (DIEP) & 279 & No & IMA/IMV & $\begin{array}{l}\text { Venous } \\
\text { thrombosis }\end{array}$ & $\begin{array}{l}\text { No } \\
\text { (unavailable) }\end{array}$ & Artery and Vein reanastomosis & Salvaged \\
\hline 12 & 41 & 29.34 & SSM & $\|$ & 360 & No & IMA/IMV & $\begin{array}{l}\text { Venous } \\
\text { thrombosis }\end{array}$ & Yes (to IMV) & $\begin{array}{l}\text { Vein reanastomosis } \\
\text { Supercharge with SIEV }\end{array}$ & Salvaged \\
\hline 13 & 48 & 20.0 & NSM & $\|$ & 400 & No & IMA/IMV & $\begin{array}{l}\text { Venous } \\
\text { thrombosis }\end{array}$ & Yes (to IMV) & $\begin{array}{l}\text { Change of Recipient vein to LTV } \\
\text { Supercharge with SIEV }\end{array}$ & Salvaged \\
\hline 14 & 36 & 22.14 & NSM & III (DIEP) & 292 & Yes (to IMV) & IMA/IMV & $\begin{array}{l}\text { Venous } \\
\text { insufficiency }\end{array}$ & No & Hematoma evacuation & Salvaged \\
\hline 15 & 44 & 24.01 & NSM & I & 627 & No & IMA/IMV & $\begin{array}{l}\text { Venous } \\
\text { thrombosis }\end{array}$ & No & Artery and vein reanastomosis & Salvaged \\
\hline 16 & 35 & 24.01 & NSM & I & 473 & No & TDA/TDV & $\begin{array}{l}\text { Venous } \\
\text { thrombosis }\end{array}$ & No & Vein reanastomosis & Salvaged \\
\hline 17 & 43 & 22.06 & NSM & I & 323 & No & LTA/LTV & $\begin{array}{l}\text { Venous } \\
\text { thrombosis }\end{array}$ & No (unavailable) & Artery and vein reanastomosis & Failed \\
\hline
\end{tabular}

BMI, body mass index; SIEV, superficial inferior epigastric vein; SSM, skin sparing mastectomy; TDA, thoracodorsal artery; TDV, thoracodorsal vein; LTV, lateral thoracic vein; DIEP, deep inferior epigastric artery perforator flap; NSM, nipple sparing mastectomy; LTA, lateral thoracic artery; IMA, internal mammary artery; IMV, internal mammary vein.

of further study. The incidence of fat necrosis in our study (36\%) was higher than in previous reports $(9.78 \%-23.4 \%)$ $[7,8]$. However, partial loss of the flaps in the salvaged group was not observed, possibly because all of the cases involved immediate reconstruction, in which most of the skin flap was buried.

The causes of free flap failure have been reported to be related to anastomotic failure due to technical errors, vasospasm, or thrombogenesis [9]. Muscle-sparing TRAM flaps and DIEP flaps were developed to minimize donor site morbidity in comparison with earlier techniques $[10,11]$. However, the inclusion of only a few large perforators along with the sacrifice of many perforators can interrupt the connection to the superficial venous system, resulting in insufficient venous drainage. Venous congestion has been identified as a major disadvantage of the DIEP flap [12-14]. The majority of the 17 cases of take-back operations in our study involved venous problems, except for one case of arterial insufficiency. This may have been because venous anastomosis is more technically demanding, and veins are more prone to vasospasm and thrombosis. However, the fact that muscle-sparing TRAM flaps and DIEP flaps have the inherent drawback of venous insufficiency is another critical factor. Signs of venous congestion can be recognized during the operation, such as immediately after flap elevation or vessel anastomosis. Rapid refill, dark blood oozing at the flap margin, and an engorged SIEV are clear indicators that venous augmentation with SIEV anastomosis is necessary. However, some cases involve ambiguous signs of venous congestion that can lead surgeons to overlook the seriousness of the state of the flap. The congestion can accumulate and develop into serious flap compromise after completion of the operation. Whatever the cause 
Table 2. Comparison of basic and microsurgical factors between the salvaged group and the failed group

\begin{tabular}{|c|c|c|c|}
\hline Characteristic & $\begin{array}{c}\text { Salvaged } \\
\text { group } \\
(n=14)\end{array}$ & $\begin{array}{l}\text { Failed } \\
\text { group } \\
(n=3)\end{array}$ & P-value ${ }^{a)}$ \\
\hline Age (yr) & 40.2 & 39.3 & 0.799 \\
\hline BMI $\left(\mathrm{kg} / \mathrm{m}^{2}\right)$ & 23.3 & 21.3 & 0.313 \\
\hline Axillary dissection & & & 0.676 \\
\hline No & $10(71.4)$ & $2(66.7)$ & \\
\hline Yes & $4(28.6)$ & $1(33.3)$ & \\
\hline Muscle sparing & & & 0.999 \\
\hline 1 & $3(21.4)$ & $1(33.3)$ & \\
\hline$\|$ & $3(21.4)$ & 0 & \\
\hline III (DIEP) & $8(57.1)$ & $2(66.7)$ & \\
\hline No. of anastomosed vein & & & 0.535 \\
\hline 1 & $11(78.6)$ & $3(100.0)$ & \\
\hline 2 & $3(21.4)$ & 0 & \\
\hline Recipient artery & & & 0.222 \\
\hline IMA & $8(57.1)$ & $1(33.3)$ & \\
\hline LTA & 0 & $2(66.7)$ & \\
\hline TDA & $6(42.9)$ & 0 & \\
\hline Recipient vein & & & 0.228 \\
\hline IMV & $8(57.1)$ & $1(33.3)$ & \\
\hline LTV & 0 & $1(33.3)$ & \\
\hline TDV & $6(42.9)$ & $1(33.3)$ & \\
\hline SIEV used in revision procedure & & & 0.124 \\
\hline No & $6(42.9)$ & $3(100.0)$ & \\
\hline Yes & $8(57.1)$ & 0 & \\
\hline \multicolumn{4}{|c|}{$\begin{array}{l}\text { BMI, body mass index; DIEP, deep inferior epigastric artery perforator flap; IMA, } \\
\text { internal mammary artery; LTA, lateral thoracic artery; TDA, thoracodorsal artery; } \\
\text { IMV, internal mammary vein; LTV, lateral thoracic vein; TDV, thoracodorsal vein; } \\
\text { SIEV, superficial inferior epigastric vein. } \\
\text { alFisher's exact test for categorical variables, two-sample t-test for continuous } \\
\text { variables. }\end{array}$} \\
\hline
\end{tabular}

of the venous congestion, the solution should attempt to re-establish venous outflow. We performed thrombectomy and reanastomosis of the DIEV in 11 cases and SIEV anastomosis in eight cases. In the other seven cases of venous congestion, we did not use the SIEV because it was unavailable or already irreversibly thrombosed. As the superficial venous system can be the dominant path of venous drainage in abdominal perforator flaps $[7,15]$, the SIEV may play a more important role in the revision operation, and it would be preferable to connect the SIEV independently to alternative recipients. Targets may include the thoracodorsal, external jugular, lateral thoracic, intercostal, cephalic, and thoracoacromial veins, or even the contralateral internal mammary vein $[16,17]$. In our cases, we used SIEV turbocharging to a branch of the DIEV or supercharging to the thoracodorsal vein, internal mammary vein, or lateral thoracic vein. Preparing the SIEV over the greatest length possible during the primary operation is the best way to cope with the unpredictable occurrence of venous congestion. It is notable that in patients with a Pfannenstiel incision scar, the SIEV is less
Table 3. Comparison of the time intervals for the recognition of signs of flap compromise and the initiation of the revision operation

\begin{tabular}{|c|c|c|c|c|}
\hline Time value & $\begin{array}{l}\text { Average } \\
\text { time (hr) }\end{array}$ & $\begin{array}{l}\text { Standard } \\
\text { deviation }\end{array}$ & $\begin{array}{c}\text { Standard } \\
\text { error of } \\
\text { mean }\end{array}$ & P-value ${ }^{a)}$ \\
\hline $\begin{array}{l}\text { Time from primary } \\
\text { operation to signs of } \\
\text { compromise (A) }\end{array}$ & & & & 0.023 \\
\hline Salvaged group & 16.57 & 12.09 & 3.23 & \\
\hline Failed group & 3.00 & 1.00 & 0.57 & \\
\hline $\begin{array}{l}\text { Time from signs of } \\
\text { compromise to revision } \\
\text { operation (B) }\end{array}$ & & & & 0.032 \\
\hline Salvaged group & 4.82 & 3.46 & 0.92 & \\
\hline Failed group & 29.00 & 24.06 & 13.89 & \\
\hline
\end{tabular}

likely to be the dominant venous drainage, and is often absent [18]. In the current study, while all eight cases with SIEV use were successfully salvaged, we did not prove that the use of the SIEV in the revision operation increased the flap salvage rate. Due to the low incidence of failure and revision in the breast reconstruction patients included in our study, we were only able to review a small number of flap failure cases, which reduced the statistical power of our analysis.

In the present study, we observed that most of the microvascular complications occurred within 24 hours after the first operation, and that the early detection of any signs indicative of microvascular compromise was essential for successfully salvaging a flap. However, in three of the cases of failed flaps, while the microvascular compromise signs were noticed earlier than the salvaged group, the surgical interventions were delayed for much longer. As the signs were not apparent at first, the flap compromise was mistaken for temporary vasospasm, and the decision to perform the take-back operation was not made in a timely manner. The unexpectedly early onset of the signs of vascular compromise might confuse the surgeons and impede the performance of a revision operation, because vasospasm could be one of the causes of early signs of compromise. Based on our observations, we argue that a prompt decision to perform flap revision after detecting the signs of microvascular complications and performing the re-exploration immediately are critical to a successful salvage outcome. Rapid and proper intervention to correct microvascular compromise is as important as the early detection of the signs of a compromised flap.

The re-exploration of microvascular complications in free lower abdominal flap breast reconstruction procedures resulted in a salvage rate of $82 \%$ in the current case series. Once the signs of flap compromise are detected, prompt decision-making regard- 
ing the take-back operation is likely to increase the success rate of the salvage procedures.

\section{REFERENCES}

1. Selber JC, Angel Soto-Miranda M, Liu J, et al. The survival curve: factors impacting the outcome of free flap take-backs. Plast Reconstr Surg 2012;130:105-13.

2. Chen KT, Mardini S, Chuang DC, et al. Timing of presentation of the first signs of vascular compromise dictates the salvage outcome of free flap transfers. Plast Reconstr Surg 2007;120:187-95.

3. Mirzabeigi MN, Wang T, Kovach SJ, et al. Free flap takeback following postoperative microvascular compromise: predicting salvage versus failure. Plast Reconstr Surg 2012; 130:579-89.

4. Koshima I, Soeda S. Inferior epigastric artery skin flaps without rectus abdominis muscle. BrJ Plast Surg 1989;42:645-8.

5. Galanis C, Nguyen P, Koh J, et al. Microvascular lifeboats: a stepwise approach to intraoperative venous congestion in DIEP flap breast reconstruction. Plast Reconstr Surg 2014; 134:20-7.

6. Yueh JH, Slavin SA, Adesiyun T, et al. Patient satisfaction in postmastectomy breast reconstruction: a comparative evaluation of DIEP, TRAM, latissimus flap, and implant techniques. Plast Reconstr Surg 2010;125:1585-95.

7. Chin SW, Hwang WJ, Ahn HC. Fat necrosis in reconstructed breast using free TRAM flap.J Korean Soc Plast Reconstr Surg 2003;30:405-12.

8. Andrades P, Fix RJ, Danilla S, et al. Ischemic complications in pedicle, free, and muscle sparing transverse rectus abdominis myocutaneous flaps for breast reconstruction. Ann Plast Surg 2008;60:562-7.

9. Wei FC, Tay SK. Principle and techniques of microvascular surgery. In: Neligan PC, Gurtner GC, editors. Plastic surgery. 3rd ed. London: Elsevier; 2012. p.587-621.

10. Nahabedian MY, Momen B, Galdino G, et al. Breast Reconstruction with the free TRAM or DIEP flap: patient selection, choice of flap, and outcome. Plast Reconstr Surg 2002;110:466-75.

11. Blondeel N, Vanderstraeten GG, Monstrey SJ, et al. The donor site morbidity of free DIEP flaps and free TRAM flaps for breast reconstruction. Br J Plast Surg 1997;50:322-30.

12. Tran NV, Buchel EW, Convery PA. Microvascular complications of DIEP flaps. Plast Reconstr Surg 2007;119:1397405.

13. Blondeel PN, Arnstein M, Verstraete K, et al. Venous congestion and blood flow in free transverse rectus abdominis myocutaneous and deep inferior epigastric perforator flaps. Plast Reconstr Surg 2000;106:1295-9.

14. Ali R, Bernier C, Lin YT, et al. Surgical strategies to salvage the venous compromised deep inferior epigastric perforator flap. Ann Plast Surg 2010;65:398-406.

15. Sbitany H, Mirzabeigi MN, Kovach SJ, et al. Strategies for recognizing and managing intraoperative venous congestion in abdominally based autologous breast reconstruction. Plast Reconstr Surg 2012;129:809-15.

16. Wechselberger G, Schoeller T, Bauer T, et al. Venous superdrainage in deep inferior epigastric perforator flap breast reconstruction. Plast Reconstr Surg 2001;108:162-6.

17. Eom JS, Sun SH, Lee TJ. Selection of the recipient veins for additional anastomosis of the superficial inferior epigastric vein in breast reconstruction with free transverse rectus abdominis musculocutaneous or deep inferior epigastric artery perforator flaps. Ann Plast Surg 2011;67:505-9.

18. Park YJ, Kim EK, Yun JY, et al. The influence of pfannenstiel incision scarring on deep inferior epigastric perforator. Arch Plast Surg 2014;41:542-7. 